ANADOLU JOURNAL OF EDUCATIONAL SCIENCES INTERNATIONAL

DOI: 10.18039/ajesi.876609

\title{
An Investigation on Metacognitive Listening Strategy Use and Listening Anxiety in EFL Classrooms
}

\author{
Elçin ÖLMEZER ÖZTÜRK ${ }^{1}$
}

Date Submitted: 08.02.2021 Date Accepted: 14.06.2021

Type ${ }^{2}$ : Research Article

\begin{abstract}
Employing a survey design, this study aims to examine learners' metacognitive listening strategies, their listening anxiety and whether there is a relationship between these two research matters in English as a foreign language (EFL) classrooms. The participants included 112 freshman students at a university context and they were taking a listening and comprehension course during the study. Two scales were used to collect the data for this study; Foreign Language Listening Anxiety Scale (FLLAS) was used to measure the participants' listening anxiety and Metacognitive Awareness Listening Questionnaire (MALQ) was used to identify their strategy use. The collected data were analysed by using a statistical program and with the help of descriptive statistics. The findings revealed that the participants experienced a moderate level of foreign language listening anxiety. In terms of their metacognitive listening strategy use, problem solving strategies were found to be used the most while mental translation strategies were used the least. It was also found that there was a low positive relationship between the participants' listening anxiety and their listening strategy use. Furthermore, no significant change was found among low, moderate and high anxious learners in terms of the types of their metacognitive listening strategy use. Parallel with those findings, the study offers several suggestions for practitioners to apply in language classrooms and for researchers to further investigate the nature of these two phenomena.
\end{abstract}

Keywords: foreign language listening anxiety, metacognitive strategy use, Turkish EFL learners

Cite: Ölmezer Öztürk, E. (2021). An investigation on metacognitive listening strategy use and listening anxiety in EFL classrooms. Anadolu Journal of Educational Sciences International, 11(2), 737-751. https://doi.org/10.18039/ajesi.876609

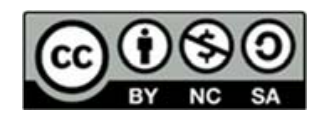

\footnotetext{
1 (Corresponding author) Dr., Anadolu University, Faculty of Education, Department of Foreign Language Education, Turkey, elcinolmezerozturk@anadolu.edu.tr, https://orcid.org/0000-0001-7743-6361

${ }^{2}$ This research study was conducted with Research Ethics Committee approval of Anadolu University, Faculty of Education, dated 29.01.2021 and issue number 2655.
} 


\section{Introduction}

Among all skills, listening has an important place in daily life and instructional processes since almost half of the communication between individuals is allocated to listening skill (Mendelsohn, 1994; Vandergrift, 2002). On the other hand, the importance of listening in language classrooms lies behind the fact that it is crucial to comprehend the input so that learning can take place (Yang, 2009). However, most students and teachers regard listening as a Cinderella skill in language classrooms (Flowerdew, 1994; Nunan \& Miller, 1995) because not many learners and teachers give enough importance to this skill. Most of the time, learners who want to improve their listening skills are on their own and they do not receive sufficient support in their learning process (Vandergrift \& Goh, 2012). Though many scholars put listening skill at the heart of the language learning process, it did not receive the same attention in terms of investigating its unique nature (Vandergrift, 2007). Not receiving enough attention in both research and practice led to the situation that listening is the weakest skill for learners (Vandergrift \& Goh, 2012). Apart from being the weakest skill of all, listening is also the most difficult one to learn due to being the least explicit among all skills (Vandergrift, 2004).

Needless to say, as a skill, listening is not a simple issue; rather, it is a complicated process (Oxford, 1993) in which the combination of various elements such as vocabulary, sounds, stress, grammar, intonation plays a crucial role (Vandergrift, 1999). In this active process, listeners try to combine all the auditory inputs coming from outside sources in order to comprehend the message (Thompson \& Rubin, 1996). In this process, learners obtain and construct meaning from aural messages, try to form a link between what they already know and the incoming message, and give a response to verbal or nonverbal messages (Nunan, 1999). The listening skills of the learners do not function separately; rather, they are all together performing simultaneously (Anderson \& Lynch, 1988). By means of listening, learners obtain and interact with language input and, as a consequence, this leads to the emergence of other skills (Vandergrift \& Goh, 2012).

Along with the sequence learners follow while listening, Young (1997) suggested that learners also have the tendency to follow a pattern concerning strategy use, starting from making inferences to interact with the text. Oxford (1990) drew attention to the importance of strategies by uttering that learners' communicative competence is highly interrelated with the strategies they use, and stated that language learning strategies are vital tools for self-directed learning. The types of strategies language learners employ were put forward by various scholars in the literature. To start with, Wenden and Rubin (1987) divided those strategies into three; social strategies, communication strategies, and learning strategies. On the other hand, Oxford (1990) classified strategies in two major groups as direct strategies, which included cognitive, memory and compensation ones, and indirect strategies that covered social, affective and metacognitive ones. Focusing on metacognitive strategies solely, Vandergrift et al. (2006), whose categorization was followed throughout the current study, came up with five subparts of metacognitive strategies and designed Metacognitive Awareness Listening Questionnaire (MALQ) to identify what strategies are used by EFL listeners.

According to this categorization (Vandergrift et al. 2006), language learners potentially benefit from five types of metacognitive strategies while listening in the target language; planning and evaluation, problem solving, mental translation, personal knowledge and directed attention. Learners using planning and evaluation strategies try to refer to their prior knowledge and form a plan whereas learners with mental translation tend to translate into their first language while performing a listening task. On the other hand, students benefiting from direct 
attention try to have a complete focus and attention on the listening task and perceive this as the key for successful comprehension (Kaplan \& Berman, 2010). Learners with problem solving strategies tend to perceive the task like a problem solving process to handle comprehension difficulties. Finally, students trying to perform the tasks based on their own existing knowledge about the target language show tendency towards personal knowledge.

\section{Listening, Metacognition and Anxiety}

In line with aforementioned strategies, increasing learners' awareness or metacognition in listening has been the concern of many teachers recently (Vandergrift \& Tafaghodtari, 2010), and it has been supported by many scholars in the literature (Bozorgian, 2014; Vandergrift, 2007; Vandergrift \& Goh, 2012). Metacognition was defined as "thinking about thinking" (Yang, 2009 , p. 135) and "the ability of learners to control their thoughts and to regulate their own learning" (Vandergrift \& Goh, 2012, p. 5). Learners should be engaged with metacognitive activities about listening in language classrooms because of the fact that these activities help learners understand themselves as learners better, make them more aware regarding their foreign language listening process, and enable them to control learning and comprehension at the same time (Vandergrift \& Goh, 2012).Besides, these metacognitive activities encourage learners to be more self-regulated and self-directed as learners (Goh, 2008). Vandergrift et al. (2006) stated that metacognitively aware learners are better at processing and storing new information, and it is more likely that they find the best option to practice what they have learned. What is more, researchers have agreed upon the idea that metacognition activates how learners think and understand (Baker, 2002; Wenden, 1998).

Though having similar patterns in strategy use, Young (1997) also drew attention to the importance of individual differences in listening, highlighting the fact that any factors deriving from individual characteristics of learners might have a crucial role in the development of their foreign language listening skills. Parallel to this, Goh (2000) stated that all language learners experience problems while they are listening to the target language. For Yang (2009), these problems could be classified as external and internal problems, and anxiety is regarded as one of the internal problems learners experience associated with their unique affective or individual characteristics. According to Horwitz et al. (1986), foreign language anxiety is directly related with the state of feeling tension and apprehension for learning a foreign language in a classroom atmosphere. The reason why learners feel anxious while listening was voiced by Vandergrift and Goh (2012): They have to demonstrate what they have understood from the listening texts in the classroom, which makes them feel anxious owing to negative connotations attached to the texts by the learners. Apart from showing what they have comprehended from the text, they have to respond in an appropriate way which is also demanding for the learners. These all increase the anxiety levels of EFL listeners.

\section{Related Studies}

Studies in the related literature examine foreign language listening anxiety and metacognitive strategies in several ways. For instance, investigating the relationship among listening anxiety, proficiency and metacognitive strategies, Han (2014) reported a negative correlation between anxiety and proficiency, and a significant difference in the use of metacognitive strategies among participants. In another study, Golzadeh and Moiinvaziri 
(2017) aimed to identify the relationship between these two constructs with a special emphasis on the role of proficiency level and gender. They found that gender had no significant effect on anxiety and strategy use while listening and upper-intermediate students felt more anxious compared to their peers with advanced level of proficiency. On the other hand, in a large scale study with 560 participants, Xu (2017) demonstrated the mediating effect of metacognitive awareness on the relationship among listening anxiety, listening test score and interest.

When literature is examined, it can also be seen that many studies related to listening and strategy use focus on the relationship between listening performance of the EFL listeners and whether their strategy use makes a difference based on their listening competency (Goh, 2000; Goh \& Hu, 2014; Vandergrift, 2003; Yang, 2009). The investigation of the differences between less-skilled and more-skilled L2 listeners has shown that there exist certain differences between them in relation to how they regulate their own listening processes, which has led to the emergence of the studies focusing on metacognitive strategies used by EFL learners. Vandergrift (2003) demonstrated that skilled listeners made use of more metacognitive strategies while listening when compared to less-skilled listeners. Besides, Yang (2009) aimed to explore the metacognitive strategies used by EFL learners in listening in China, and revealed that learners mostly used direct attention and monitoring strategies were preferred the least. With respect to self-management, functional planning, and directed attention, a significant difference was found between less skilled listeners and their more skilled counterparts. What is more, Goh and $\mathrm{Hu}(2014)$ investigated the relationship between the use of metacognitive strategies of 113 Chinese EFL learners and their listening scores, and found a significant positive relationship revealing that the increase in strategy use resulted in an increase in their listening performance. In a similar but more recent study, Baniadam et al. (2019) examined the relationship between metacognitive awareness and listening performance among students within the scope of an English for general purposes course. The findings revealed a weak positive relationship between these two constructs, but in specific, problem solving and directed attention were found to have more correlation with the listening performance.

In addition to those, some bulk of research aimed to investigate the impact of strategy training on metacognitive awareness and listening performance. Having an experimental research design, Coşkun (2010) divided the participants as experimental and control groups, and the experimental group was taught metacognitive strategies in listening. Listening tests were administered as pre and post tests for both groups. The results demonstrated that the ones exposed to metacognitive strategy training in listening outperformed the control group. Ceylan (2016) examined 240 Turkish university students' metacognitive strategies and listening scores and revealed a positive correlation between them. Moreover, in the same study, a positive correlation was also identified among directed attention, planning and evaluation, and problem solving. In another study, Taheri and Zade (2018) identified whether metacognitive strategies contributed to students' listening comprehension performance and their metacognitive awareness. The data derived from their experimental design put forward that the participants' both metacognitive awareness and listening comprehension performance increased dramatically after the strategy training. Similarly, Kobayashi (2018) also examined the impact of metacognitive strategy instruction on listening for sophomore EFL learners and reported that the group with strategy instruction gained more listening proficiency and the regulation of cognition. Finally, in a quite recent study, Yetiş (2021) aimed to explore the effect of an 8-week metacognitive instruction on 37 EFL learners' listening comprehension performance and metacognitive awareness using both quantitative and qualitative data 
collection elements. The findings indicated that the group with the instruction showed a significantly higher metacognitive awareness and listening performance.

The link between listening anxiety levels of the learners and their metacognitive strategy uses was also the starting point of few studies in the literature (Berber \& Kuru Gönen, 2017; Dalman, 2016; Golchi, 2012). For instance, Golchi (2012) investigated whether there is a link between anxiety, listening proficiency and listening strategy of the learners. The data obtained from 63 EFL listeners indicated a negative correlation between anxiety, listening proficiency and listening strategy of the learners, and low anxious learners were found to be using more strategies than their high anxious peers. To investigate the relationship between listening anxiety and listening comprehension strategies of the learners, Dalman (2016) studied with 110 Iranian EFL learners. The findings showed that the participants made use of metacognitive strategies most and there was a negative correlation between the listening anxiety and learners' listening comprehension strategies. In other words, less anxious learners tended to utilize listening comprehension strategies more. Another study belongs to Berber and Kuru Gönen (2017) who focused on the use of listening comprehension strategies by high and low anxious learners. The participants were 15 high anxious and 13 low anxious FL learners, and the data were collected through reflections and semi-structured-interviews. The findings revealed that both groups resorted to various listening comprehension strategies under the headings of cognitive and metacognitive strategies. Low anxious learners utilized more cognitive and metacognitive strategies than high anxious learners.

\section{The Problem Situation and The Purpose of The Study}

Though listening as a skill has greater emphasis in language classrooms, listening in the classroom still focuses on textbooks and communication, and it is not learner-oriented (Vandergrift \& Goh, 2012). In other words, how learners listen, and what they do to maximize the effectiveness of their listening skills are not given enough emphasis. Besides, though the importance of metacognition and anxiety is mostly focused in the literature (Baker, 2002; Sun, 2013; Wenden, 1998; Zheng \& Cheng, 2018), they were mostly covered separately. Thus, investigation of these two phenomena, their potential relationship or effect on each other are yet to be discovered.

In addition to that, though a number of studies focus on foreign language listening anxiety and metacognitive strategies, there is still a paucity of research investigating the relationship between these two constructs. Moreover, literature in recent years, especially in Turkish EFL context, lacks the investigation of this relationship, and the most recent findings on this topic belong to Berber and Kuru Gönen (2017) who also maintained that "exploration of identifying which FL listening comprehension strategies have correlation with FL listening anxiety would shed light on the relationship between anxiety and strategy use" (p.101). Considering this call for more investigation on this research matter and addressing to the lack of research in recent literature, this study aims to examine the link between metacognitive strategy use and anxiety levels of the learners. Within this purpose, the following research questions were addressed throughout the study:

1. What is the level of foreign language listening anxiety experienced by Turkish EFL learners? 
2. Which metacognitive strategies do Turkish EFL learners use in foreign language listening?

3. What is the relationship between Turkish EFL learners' metacognitive strategy use and their foreign language listening anxiety?

3.a. Does the use of metacognitive strategies change according to the foreign language listening anxiety level of the participants?

\section{Methodology}

\section{Research Design}

The current study employs a survey design in which researchers administer a survey to a sample of participants to learn about their characteristics and attitudes on the research matter (Creswell, 2012). In survey designs, the data are collected through questionnaires, analysed statistically, and findings derived from the statistical analysis are interpreted in line with the ones in the literature. Since the study aims to examine the anxiety level of EFL learners and their metacognitive strategy use via questionnaires and the main purpose is to obtain their characteristics on these two research matters, the phases throughout the study are in line with the one in a survey design.

\section{Participants}

The participants of the study included 112 freshman students in the department of English language teaching at a state university in Turkey. They were determined through convenience sampling in which the participants are selected since they are available and willing to be studied and they can provide useful information for research questions (Creswell, 2012). Having a background of ten years language learning, the participants start their university program after getting required scores in a national university entrance exam in which they answer questions on their English language proficiency. After they register for the program, they also have to pass an English proficiency exam administered by their university to demonstrate their proficiency to study in the English language teaching department. Since all the participants successfully passed all those stages, their proficiency level is upperintermediate or higher. Their ages ranged from 18 to 20 , and 67 of them were female and the other 45 were male students.

\section{Data Collection Instruments}

The study employed two main data collection tools. The first one was Metacognitive Awareness Listening Questionnaire (MALQ) that was developed by Vandergrift et al. (2006). It has been commonly used in the literature, and in the current study, due to its clear categorization of strategies and its correlational validation with listening comprehension. To specify, MALQ measures language learners' metacognitive awareness on listening strategy use. The questionnaire is composed of 21 Likert-type items under five sub-constructs as planning and evaluation (items; 1, 10, 14, 20, 21), problem solving (items; 5, 7, 9, 13, 17, 19), mental translation (items; 4, 11, 18), personal knowledge (items; 3, 8, 15), and directed attention (items; $2,6,12,16$ ). The reliability and validity of the questionnaire were reported as 
high parallel with the correlation between students' listening comprehension success and their responses on the instrument (Vandergrift et al., 2006). In the current study, the Cronbach alpha was found as .91 , referring to a high level of inner consistency.

The second data collection instrument was Foreign Language Listening Anxiety Scale (FLLAS) developed by Kim (2000). In the literature of anxiety research, FLLAS has kept an important place and has been commonly used in many studies since it was developed and validated based on a thorough process and it belonged a high level of reported reliability. Specifically validated to measure the level of listening anxiety among EFL learners, the scale was constructed as a 33-item Likert scale after a thorough process including reviewing the literature, interviewing learners, creating an item pool and reducing the number of items based on the relevance and similarities. The scale also included four items $(6,14,25,31)$ that should be reverse-coded during the analysis and the inner consistency of it was reported as .93, being highly reliable.

\section{Ethical Issues, Data Collection and Analysis}

First of all, approval for the research process was taken from Research Ethics Committee of Anadolu University (issue number 2655). After that, the students who participated in the study were asked to sign consent forms confirming that they volunteered to take part in it. After the researcher informed them about the research process, the questionnaires used in the study were answered by 120 students who were taking the listening and comprehension course. While they were answering the items in the questionnaires, the researcher was there in case the students might need her or have some questions. Among them, 112 participants completed all the items in the questionnaires, and eight had to be eliminated owing to incomplete answers. Thus, the final number of the participants was 112 .

A statistical software program was used to analyse the data. In order to reveal the foreign language listening anxiety level of the participants and their metacognitive listening strategies, descriptive statistics were utilized. Finally, Pearson correlation was used to identify the relationship between anxiety level and metacognitive listening strategies, and one-way ANOVA was employed to see whether the use of each strategy type differed according to the anxiety levels of learners.

\section{Findings}

\section{Foreign Language Listening Anxiety (FLLA) of Learners}

The first focus of the study aimed to examine the FLLA level of the participants, and to find out this, the formula suggested by Aydın (1999) was followed. According to this formula, participants with the mean score that is lower than "Mean (M) - Standard Deviation (SD)" are low anxious learner. Participants whose mean scores are higher than " $M+S D$ " are highly anxious learners. The ones with the mean scores between high and low are accepted as moderately anxious learners. In line with this formula, the findings are presented in Table 1: 
Table 1

Foreign Language Listening Anxiety Level of the Participants

\begin{tabular}{lccccc}
\hline & N & Min. & Max & Mean & SD \\
\hline Anxiety-total & 112 & 1.06 & 4.18 & 2.48 & .66 \\
\hline Low & N & Percentage & Mean \\
Moderate & 16 & 14.3 & Lower than 1.82 \\
High & 78 & & 70.5 & $1.82-3.14$ \\
\hline
\end{tabular}

As seen in the table, the results showed that the participants experienced a moderate level of FLLA (2.48) while listening in the target language. Besides, it was revealed that around $70 \%$ of the participants were moderately anxious whereas $14.3 \%$ experienced low levels of anxiety and $15.2 \%$ of the participants were highly anxious.

\section{Metacognitive Listening Strategy (MLS) Use of Learners}

The second focus of the current study was to examine the types of MLS employed by the participants while listening in the target language. The findings regarding this focus are presented in Table 2.

Table 2

Metacognitive Listening Strategies of the Participants

\begin{tabular}{lccccc}
\hline Strategy type & N & Min. & Max & Mean & SD \\
Problem solving & 112 & 1.00 & 5.00 & 3.91 & .60 \\
\hline Directed attention & 112 & 2.00 & 5.00 & 3.33 & .48 \\
\hline Planning and evaluation & 112 & 1.40 & 4.80 & 3.21 & .67 \\
\hline Personal knowledge & 112 & 1.67 & 5.00 & 3.19 & .62 \\
\hline Mental translation & 112 & 1.00 & 5.00 & 2.75 & .98 \\
\hline
\end{tabular}

The findings revealed that the participants preferred problem solving strategies most (Mean= 3.91) while listening in the target language whereas mental translation $(M=2.71)$ was found to be the least preferred strategy among learners. Directed attention strategies was the second most preferred strategy type $(M=3.33)$, planning and evaluation as the third $(M=3.21)$ and personal knowledge strategies as the fourth $(M=3.19)$. 


\section{The Relationship between Metacognitive Listening Strategies and Foreign Language Listening Anxiety Level}

The last research question aimed to identify the relationship between FLLA and MLS among the participants and reveal whether the use of those strategies changed according to the FLLA level of the learners. First, the normality assumption was tested to decide on the correct analysis method within the scope of this research question. At this point, since small differences between observed and expected distributions tend to be significant as the sample size increases in the Kolmogorov-Smirnov test (Çokluk, et al., 2010; Sprent \& Smeeton, 2007), Shapiro-Wilk test was preferred. Besides, Shapiro-Wilk was also demonstrated in numerous studies to be the most powerful test used to evaluate normality assumption (Demir, et al. 2016; Özer, 2007; Shapiro et al., 1968). Table 3 shows the results derived from the Shapiro-Wilk analysis.

Table 3

Results of the Normality Assumption

\begin{tabular}{lccc}
\hline Scale & Statistic & df & Sig. \\
\hline Metacognitive listening strategy & .98 & 112 & .20 \\
Foreign language listening anxiety & .97 & 112 & .06 \\
\hline $\mathrm{p}>.05$ & & &
\end{tabular}

According to the results, it was seen that both foreign FLLA and MLS meet the normality assumption $(p>.05)$. In the light of this result, it was concluded that the statistical analysis to be conducted using the mentioned measures should be carried out with parametric methods. In this regard, to identify their relationship, Pearson correlation was employed and the results are presented in Table 4.

Table 4

The Relationship Between Anxiety Level and Strategies

\begin{tabular}{llcc}
\hline & & $\begin{array}{c}\text { Listening } \\
\text { Anxiety }\end{array}$ & $\begin{array}{c}\text { Metacognitive strategy } \\
\text { use }\end{array}$ \\
\hline \multirow{2}{*}{ Listening anxiety } & Pearson & 1 & $.22^{*}$ \\
& Correlation & & .01 \\
& Sig. (2-tailed) & 112 & 112 \\
& $\mathrm{~N}$ & &
\end{tabular}

${ }^{*} p<.05$

As seen in the results, a significantly positive relationship ( $r: 22)$ was found between FLLA levels and MLS use of the participants, but this relationship was on a low level. That means, if the FLLA level of the participants increases, the use of MLS is likely to increase in a low level. After that, one-way ANOVA was utilized to see whether the use of MLS changed 
according to the FLLA level of the learners - low, moderate and high - and this change is significant or not. The results derived from the analysis are shown in Table 5.

\section{Table 5}

Metacognitive Listening Strategy Types and Anxiety Levels

\begin{tabular}{|c|c|c|}
\hline Strategy type & Means & Sig. value $(p<.05)$ \\
\hline Problem solving & $\begin{array}{c}\text { Low } 3.90 \\
\text { Moderate } 3.93 \\
\text { High } 3.86\end{array}$ & .94 \\
\hline Mental translation & $\begin{array}{c}\text { Low } 2.04 \\
\text { Moderate } 2.89 \\
\text { High } 2.74\end{array}$ & .88 \\
\hline Directed attention & $\begin{array}{c}\text { Low } 3.41 \\
\text { Moderate } 3.31 \\
\text { High } 3.31\end{array}$ & .79 \\
\hline Planning and evaluation & $\begin{array}{c}\text { Low } 2.89 \\
\text { Moderate } 3.22 \\
\text { High } 3.42\end{array}$ & .59 \\
\hline Personal knowledge & $\begin{array}{c}\text { Low } 2.95 \\
\text { Moderate } 3.17 \\
\text { High } 3.47\end{array}$ & .25 \\
\hline
\end{tabular}

As seen in the table, the findings indicated no significant difference in terms of the types of MLS used by the participants with low, moderate and high anxious learners, which means that the type of the strategy use does not change according to the FLLA level of the students. On the other hand, when the mean scores are examined, it can be observed that no matter what their anxiety level is; low, moderate or high, they reported to use problem solving strategies more than the others and mental translation strategies the least.

\section{Conclusion, Discussion and Implications}

The current study had two main foci under investigation, foreign language listening anxiety and metacognitive listening strategy use. For the former one, the participants reported a moderate level of FLLA while listening in the target language. This finding is parallel with the results of the studies focusing on foreign language listening anxiety level of learners, Börekci and Yavuz (2017) and Hidayati et al. (2020), both of which demonstrated a moderate or relatively higher anxiety level in listening among EFL students. For the current study, why most learners had moderate anxiety levels could result from their proficiency levels because all of them had passed several steps in terms of their proficiency, including a listening test. In other words, since all participants had been successful in a listening exam and they perceived themselves as competent enough based on their scores, they may not be feeling highly anxious while listening in the target language. The second focus of the study was the types of MLS employed by the participants while listening in the target language. The results indicated that the most frequently used strategy was found to be problem solving, followed by directed attention and planning and evaluation whereas mental translation was the least frequently used one by the participants. The results of the current study are in line with Al-Alwan et al. 
(2013) who stated that 386 EFL learners in Jordan used problem solving strategies the most whereas personal knowledge was resorted to the least by those learners. Also, the findings of the current study could be supported by Goh and Hu (2014) who expressed that the participants in their study made use of problem solving strategies and directed attention the most. The main reason behind the participants' preference of problem solving and directed attention strategies might be due to the fact that these strategies help them overcome comprehension difficulties more when they listen to a text in the target language, as demonstrated by several studies focusing on the metacognitive strategy preferences of foreign language learners (Lee \& Mukhlynina, 2017; Selamat \& Sidhu, 2013; Yang, 2009).

Moreover, the findings of this study demonstrated that there was a significantly positive relationship between FLLA levels and MLS use of the participants though on a low level. This finding is not in line with most of the studies in the field. For instance, Gönen (2009) identified a negative relationship between these two constructs and revealed that when there was an increase in the anxiety levels of the learners, a decrease was found in the use of metacognitive strategies. The same negative correlation was expressed in Golchi (2012) and Berber and Kuru Gönen (2017)'s studies that low anxious learners utilized more metacognitive strategies, and also in Golzadeh and Moiinvaziri (2017) who voiced that though weak, there was a negative correlation between listening anxiety and metacognitive strategy use of the learners. Contrary to those, the current study reported a low positive relationship between FLLA and MLS use of learners. The reason of that could be rooted in the moderate anxiety levels of the learners in the present study. As high level of anxiety can hinder the employment of metacognitive strategy (Gönen, 2009), the participants' metacognitive strategy use was not affected negatively from their anxiety level since they had not been feeling highly anxious during listening. In that sense, it can be said that the findings of the current study related to the relationship between FLLA and MLS use were not in line with the ones in the literature.

Finally, the results also showed that there is no change among the high, moderate and low anxious learners in terms of the types of MLS used. In other words, FLLA level of the participants does not affect the type of the strategy used by learners during listening. However, Golchi (2012) revealed that low and high anxious learners differed in terms of the use of metacognitive strategies. In this study, the participants with low anxiety levels were found to use more strategies compared to their high anxious counterparts. In the same vein, Han (2014) also reported a significant difference in the use of metacognitive strategies among anxiety levels. The discrepancy between these two similar studies and the current study might be arising from the dominancy of moderate level of anxiety among the participants of the current study and might also lead us to the conclusion that though the level of anxiety has a role on the amount of strategies being used, it does not significantly influence the types of strategies during listening.

Neglected by both teachers and learners, listening as a skill has been in the shadow of the other skills unfortunately. However, there is a growing number of research studies whose focus is listening, and many research areas have been flourished under the heading listening such as problems during listening, listening anxiety, and the strategies used while listening. Aiming to shed light on two phenomena related with foreign language listening skill, this study investigated EFL learners' metacognitive listening strategy use and foreign language listening anxiety, and potential relationship between them. Carried out with 112 freshman Turkish EFL learners, the study employed questionnaires to obtain data from the participants. Relying on the data, the findings revealed that the participants of this study had mostly moderate level of 
FLLA; in other words, the moderate level anxious learners outnumbered high and low anxious learners. The learners resorted to problem solving strategies most, whereas mental translation was preferred least. Besides, though on a low level, a positive relationship was found between FLLA and MLS and no significant change was identified in terms of the strategy use according to anxiety levels of learners.

Although having several limitations such as being conducted in a specific context, having a limited number of participants and being descriptive in terms of the research perspective, this study presents an overall picture of learners with similar characteristics in contexts similar to the one the study was conducted. One cannot deny that studies in which listening anxiety and strategy use are examined hand in hand in a longitudinal way and within a deeper perspective will contribute to our understanding of the relationship of these two phenomena. In that sense, studies focusing on learner diaries during strategy training or think aloud protocol examining learners' strategy use and anxiety while listening will make a significant contribution to the field.

As for the practical implications, dictating that anxiety is a very natural feeling experienced in language learning process creating a more relaxed atmosphere in class that will help learners decrease their anxiety level will help students performs better. Besides, as demonstrated by empirical findings (Coşkun, 2010; Taheri \& Zade, 2018), the appropriate use of listening strategies contribute to listening performance, and spending more time in language classrooms on teaching students how to benefit from the strategy use more will clearly help them increase their performance in foreign language listening. Taking this contribution of strategy use into consideration, training both in-service and pre-service teachers so that they can guide their learners in terms of strategy use is probably more important than all. For this reason, organization of more trainings or workshops on metacognitive strategies for in-service teachers and integrating this topic into the curriculum of pre-service EFL teachers will definitely contribute to teachers' competency. 


\section{References}

Al-Alwan, A., Asassfeh, S., \& Al-Shboul, Y. (2013). EFL learners' listening comprehension and awareness of metacognitive strategies: How are they related? International Education Studies, 6(9), 31-39. Retrieved May 18, 2021, from https://doi.org/10.5539/ies.v6n9p31

Anderson, A., \& Lynch, T. (1988). Listening. Oxford University Press.

Aydın, B. (1999). A study of sources of foreign language classroom anxiety in speaking and writing classes. [Unpublished doctoral dissertation]. Anadolu University.

Baker, L. (2002). Metacognition in comprehension instruction. In C. Block \& M. Pressley (Eds.), Comprehension instruction: Research-based best practices (pp. 77-95). Guilford Press.

Baniadam, I., Meskini, N., \& Afra, A. (2019). The relationship between Iranian female dentistry students' metacognitive awareness and listening performance in English for general purposes (EGP). Philosophy Study, 9(7), 414-423. Retrieved May 18, 2021, from https://doi.org/10.17265/2159-5313/2019.07.005

Berber, G., \& Kuru Gönen, S. İ. (2017). How do high and low anxious FL listeners employ FL listening comprehension strategies? Exploring student perspectives. Journal of Qualitative Research in Education, 5(3), 90-108. Retrieved January 18, 2021, from https://10.14689/issn.21482624.1.5c3s4m

Borekci, R., \& Yavuz, F. (2017). Foreign language listening anxiety among Turkish EFL learners. Global Journal of Foreign Language Teaching. 7(2), 86-90. Retrieved May 18, 2021, from https://doi.org/10.18844/giflt.v7i2.2991

Bozorgian, H. (2014). The role of metacognition in the development of EFL learners' listening skill. International Journal of Listening, 28(3), 149-161. Retrieved January 18, 2021, from https://doi.org/10.1080/10904018.2013.861303

Ceylan, E. (2016). An exploratory study on the relationship between motivation types, metacognitive awaraness, and EFL listening proficiency. [Unpublished master' thesis]. Dokuz Eylül University.

Coşkun, A. (2010). The effect of metacognitive strategy training on the listening performance of beginner students. Novitas-ROYAL, 4(1), 35-50. Retrieved January 18, 2021, from https://novitasroyal.org/volume-4-issue-1-april-2010/?wpdmc=volume-4-issue-1

Creswell, J. W. (2012). Educational Research: Planning, conducting, and evaluating quantitative and qualitative research. Pearson Education.

Çokluk, Ö., Şekercioğlu, G., \& Büyüköztürk, Ş. (2010). Sosyal bilimler için çok değişkenli istatistik: SPSS ve LISREL uygulamaları. Pegem Akademi

Dalman, M. R. (2016). The relationship between listening anxiety, listening comprehension strategies, and listening performance among Iranian EFL university students, International Journal of Modern Language Teaching and Learning, 1(6), 242-256. Retrieved January 18, 2021, from http://www.ijmltl.com/fulltext/paper-01122016185800.pdf

Demir, E , Saatçioğlu, Ö.,\& İmrol, F. (2016). Uluslararası dergilerde yayımlanan eğitim araştırmalarının normallik varsayımları açısından incelenmesi. Current Research in Education, 2(3), 130-148. Retrieved January 20, 2021, from https://dergipark.org.tr/en/pub/crd/issue/28292/300531

Flowerdew, J. (Ed.) (1994). Academic listening: Research perspectives. Cambridge University Press.

Goh, C. C. M. (2000). A cognitive perspective on language learners' listening comprehension problems. System, 28, 55-75. Retrieved January 18, 2021, from https://doi.org/10.1016/S0346251X(99)00060-3

Goh, C. C. M. (2008). Metacognitive instruction for second language listening development: Theory, practice and research implications. RELC Journal, 39(2), 188-213. Retrieved January 18, 2021, from https://doi.org/10.1177/0033688208092184

Goh, C. C. M., \& Hu, G. (2014). Exploring the relationship between metacognitive awareness and listening performance with questionnaire data. Language Awareness, 23(3), 255-274. Retrieved January 18, 2020, from https://doi.org/10.1080/09658416.2013.769558 
Golchi, M. M. (2012). Listening anxiety and its relationship with listening strategy use and listening comprehension among Iranian IELTS learners. International Journal of English linguistics, 2(4), 115-128. Retrieved January 18, 2021, from $\underline{10.5539 / i j e l . v 2 n 4 p 115}$

Golzadeh, N., \& Moiinvaziri, M. (2017). Metacognitive strategy awareness and listening Anxiety: The role of gender and proficiency level among Iranian EFL learners. International Journal of Foreign Language Teaching \& Research, 5(19), 91-109. Retrieved May 20, 2021, from http://jifl.iaun.ac.ir/article 593889.html

Gönen, M. (2009). The relationship between FL listening anxiety and FL listening strategies: the case of Turkish EFL learners. 5th WSEAS/IASME International Conference on Educational Technologies, 44-49. Retrieved May 20, 2021, from http://www.wseas.us/elibrary/conferences/2009/lalaguna/EDUTE/EDUTE-05.pdf

Han, J. (2014). A study on the influence of anxiety and metacognitive strategies on listening proficiency. Journal of Chemical and Pharmaceutical Research, 6(6), 2484-2496. Retrieved May 20, 2020, from https://www.jocpr.com/articles/a-study-on-the-influence-of-anxiety-and metacognitive-strategies-on-listening-proficiency.pdf

Hidayati, A. N., Dewi, N. S. N., Nurhaedin, E., \& Rosmala, D. (2020). Foreign language listening anxiety in an academic listening class. J-SHMIC : Journal of English for Academic, 7(2), 1-9. Retrieved May 18, 2021, from https://doi.org/10.25299/jshmic.2020.vol7(2).5241

Horwitz, E. K., Horwitz, M. B., \& Cope, J. (1986). Foreign language classroom anxiety. The Modern Language Journal, 70(2), 125-132. Retrieved May 20, 2021, from https://doi.org/10.2307/327317

Kaplan, S., \& Berman, M.G. (2010). Directed attention as a common resource for executive functioning and self-regulation. Perspectives on Psychological Science, 5(1), 43-57. Retrieved May 20, 2021, from https://doi.org/10.1177/1745691609356784

Kim, J. (2000). Foreign language listening anxiety: A study of Korean students learning English. [Unpublished doctoral dissertation]. The University of Texas at Austin.

Kobayashi, A. (2018). Investigating the effects of metacognitive instruction in listening for EFL learners. The Journal of Asia TEFL, 15(2). 310-328. Retrieved May 20, 2021, from http://dx.doi.org/10.18823/asiatefl.2018.15.2.4.310

Lee, H., \& Mukhlynina, I. (2017). Listening metacognitive awareness: Case study on Chinese and Russian students in French L2. Journal of Advances in Linguistics, 8(1), 1236-1245. Retrieved May 18, 2021, from https://doi.org/10.24297/jal.v8i1.6353

Mendelsohn, D. (1994). Learning to Listen: A Strategy-Based Approach for the Second-Language Learner. Dominie Press.

Nunan, D., \& Miller, L. (1995). New ways in teaching listening. TESOL.

Nunan, D. (1999). Second language teaching and learning. Heinle and Heinle.

Oxford, R. (1990). Language learning strategies: What every teacher should know. Newbury house.

Oxford, R. L. (1993). Research update on L2 listening. System, 21, 205-11. https://doi.org/10.1016/0346-251X(93)90042-F

Özer, A. (2007). Normallik testlerinin karşılaştırılması. [Yayınlanmamış yüksek lisans tezi]. Ankara Üniversitesi.

Selamat, S., \& Sidhu, G. K. (2013). Enhancing listening comprehension: The role of metacognitive strategy instruction (MetSI). Procedia - Social and Behavioral Sciences, 90, 421-430. Retrieved May 20, 2020, from https://10.1016/i.sbspro.2013.07.111

Shapiro, S. S., Wilk, M. B., \& Chen, H. J. (1968). A comparative study of various tests for normality. Journal of The American Statistical Association, 63(324), 1343-1372. Retrieved January 20 , 2020, from https://doi.org/10.2307/2285889

Sprent, P., \& Smeeton, N. C. (2007). Applied nonparametric statistical methods (Fourth edition). CRC Press.

Sun, L. (2013). The effect of meta-cognitive learning strategies on English learning. Theory and Practice in Language Studies, 3(11), 2004-2009. Retrieved May 20, 2021, from https://doi.org/ 10.4304/tpls.3.11.2004-2009 
Taheri, P., \& Zade, M. H. (2018). The contribution of metacognitive strategies to EFL learners' listening comprehension task types. Teaching English Language, 12(2), 169-198. Retrieved January 18, 2021, from https://doi.org/10.22132/TEL.2018.82864

Thompson, I., \& Rubin, J. (1996). Can strategy instruction improve listening comprehension? Foreign Language Annals, 29(3), 331-342. Retrieved January 18, 2021, from https://doi.org/10.1111/j.1944-9720.1996.tb01246.x

Vandergrift, L. (1999). Facilitating second language listening comprehension: acquiring successful strategies. ELT Journal, 53(3), 168-176. Retrieved January 18, 2021, from https://doi.org/10.1093/elt/53.3.168

Vandergrift, L. (2002). It was nice to see that our predictions were right: Developing metacognition in L2 listening comprehension. The Canadian Modern Language Journal Review, 58, 555-575. Retrieved January 18, 2020, from https://doi.org/10.3138/cmlr.58.4.555

Vandergrift, L. (2003). From prediction through reflection: guiding students through the process of L' listening. The Canadian Modern Language Review, 59(3), 425-440. Retrieved January 18, 2021, from https://doi.org/10.3138/cmlr.59.3.425

Vandergrift, L. (2004). Learning to listen or listening to learn? Annual Review of Applied Linguistics, 24, 3-25. Retrieved January 18, 2021, from https://doi.org/10.1002/9781118784235.eelt0567

Vandergrift, L. (2007). Recent developments in second and foreign in language listening comprehension research. Language Teaching, 40, 191-210. Retrieved January 18, 2021, from https://doi.org/10.1017/S0261444807004338

Vandergrift, L., Goh, C, C. M., Mareschal, C., \& Tafaghodtari, M. H. (2006). The metacognitive awareness listening questionnaire (MALQ): Development and validation. Language Learning, 56, 431-462. Retrieved January 18, 2020, from https://doi.org/10.1111/j.14679922.2006.00373.x

Vandergrift, L., \& Tafaghodtari, M. H. (2010). Teaching L2 learners how to listen does make a difference: An empirical study. Language Learning, 60(2), 470-497. Retrieved January 18, 2021, from https://doi.org/10.1111/j.1467-9922.2009.00559.x

Vandergrift, L., \& Goh, C. (2012). Teaching and learning second language listening: Metacognition in action. Routledge.

Wenden, A., \& Rubin, J. (1987). Learner strategies in language learning. Prentice Hall.

Wenden, A. (1998). Metacognitive knowledge and language learning. Applied Linguistics, 19, 515537. Retrieved January 18, 2021, from https://doi.org/10.1093/applin/19.4.515

$\mathrm{Xu}, \mathrm{J}$. (2017). The mediating effect of listening metacognitive awareness between test-taking motivation and listening test score: An expectancy-value theory approach. Frontiers in Psychology, 8, 1-10. Retrieved January 18, 2021, from https://doi:10.3389/fpsyg.2017.02201

Yang, C. (2009). A study of metacognitive strategies employed by English listeners. International Education Studies, 2(4), 134-139. Retrieved January 18, 2020, from https://doi.org/10.5539/ies.v2n4p134

Yetiş, K. (2021). The impact of metacognitive instruction on EFL learners' listening comprehension skill. [Unpublished doctoral dissertation]. Hacettepe University.

Young, M. Y. C. (1997). A serial ordering of listening comprehension strategies used by advanced ESL learners in Hong Kong. Asian Journal of English Language Teaching, 7, 35-53. Retrieved January 18, 2020, from https://www.cuhk.edu.hk/ajelt/vol7/art3.htm

Zheng, Y., \& Cheng, L. (2018). How does anxiety influence language performance? From the perspectives of foreign language classroom anxiety and cognitive test anxiety. Language Testing in Asia, 8(13). Retrieved May 20, 2021, from https://doi.org/10.1186/s40468-018-0065-4 